LKymp9805031 C

\title{
Sustaining Native Microbial Growth with Endogenous Nutrients at Yucca Mountain
}

\author{
M.A. Davis \\ S. Martin \\ A. Miranda \\ JM. Horn
}

This paper was prepared for submittal to the

American Nuclear Society

1998 International High-Level Radioactive Waste Management Conference

Las Vegas, $N V$

May 11-14, 1998

February 1998

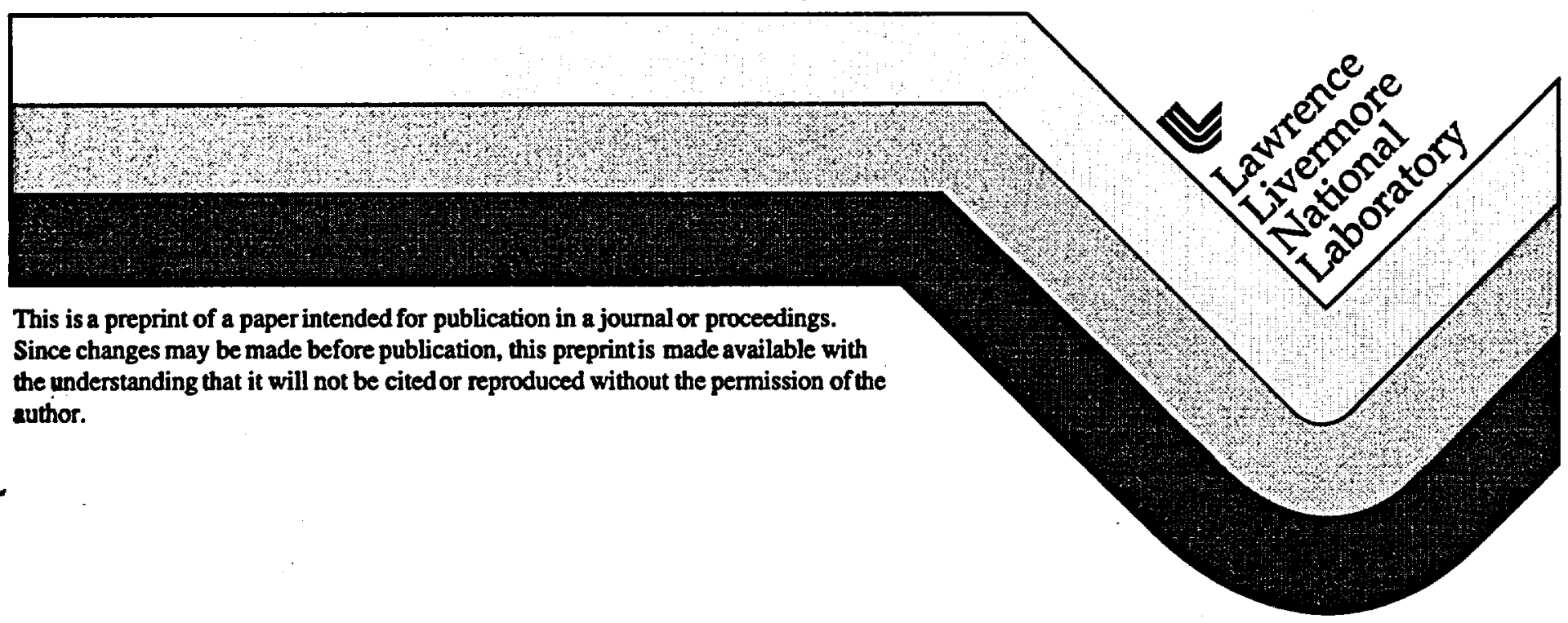




\section{DISCLAMER}

This document was prepared as an account of work sponsored by an agency of the United States Government. Neither the United States Government nor the University of Califomia nor any of their employees, makes any warranty, express or implied, or assumes any legal liability or responsibility for the accuracy, completeness, or usefulness of any information, apparatus, product, or process disclosed, or represents that its use would not infringe privately owned rights. Reference herein to any specific commercial product, process, or service by trade name, trademark, manufacturer, or otherwise, does not necessarily constitute or imply its endorsement, recommendation, or favoring by the United States Government or the University of Califomia. The views and opinions of authors expressed herein do not necessarily state or reflect those of the United States Govermment or the University of Califormia, and shall not be used for advertising or product endorsement purposes. 


\section{SUSTAINING NATTVE MICROBIAL GROWTH WTTH ENDOGENOUS NUTRIENTS AT YUCCA MOUNTAIN}

Michael A. Davis

LawrenceLivermoreLab

P.O. Box 808, L-219

Livermore, CA 94550
Sue Martin

Lawrence Livermore Lab

P.O. Box 808, L-201

Livermore, CA 94550
AnabelMiranda

Turabo University

P.O. Box 3030 Univ. Sta.

Gurabo, Puerto Rico 00778
Joanne M. Horn

Lawrence Livermore Lab

P.O. Box 808, L-206

Livermore, CA 94550

(510) 423-3949

\section{INTRODUCTION}

The integrity of candidate waste-package materials for the proposed Yucca Mountain (YM) repository may be compromised by the corrosive activities of microorganisms. Bacterial activities will be dependent on the abilities of deleterious bacteria to grow and multiply

in the repository environment. Therefore, preliminary to assessing microbial induced corrosion, experiments were undertaken to determine the growth of native YM bacterial communities in modified YM pore water. Specifically, we sought to define nutrients that limit bacterial growth in Yucca Mountain and determine growth rates under aerobic, saturated conditions.

Table 1. Comparison of the compositions of $10 X \mathrm{J13}$ pore water, M9 media, and experimental media.

\begin{tabular}{|c|c|c|c|c|c|c|c|c|}
\hline \multicolumn{9}{|c|}{ Specles Concentration (mM) } \\
\hline & $10 x-\sqrt{13}$ & M9 & $\begin{array}{c}\text { YM } \\
\text { complete }\end{array}$ & $\begin{array}{l}\text { Dilute } \\
\text { complete }\end{array}$ & $\begin{array}{l}\text { Carbon } \\
\text { deficient }\end{array}$ & J13-NO3 & J13-SO4 & $\begin{array}{c}\text { Phosphate } \\
\text { deficient }\end{array}$ \\
\hline $\mathrm{Na}^{+}$ & 19.10 & 93.12 & 130.65 & 13.07 & 130.65 & 130.00 & 130.50 & 93.00 \\
\hline 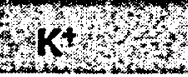 & 1512 & 22.00 & 1828 & 2183 & 18.28 & 22.01 & 2212 & W22,00 \\
\hline $\mathrm{Mg}^{2+}$ & 0.79 & 1.00 & 0.87 & 0.09 & 0.87 & 1.01 & 1.12 & 1.01 \\
\hline $\mathrm{SCa}_{2}^{2+1}$ & $31_{2}$ & Wrst & (1) & Wy & $x_{2}$ & $4 \times x$ & (3) & 10.6 \\
\hline $\mathrm{Cr}^{-}$ & 1.95 & 27.50 & 1.88 & 0.19 & 1.88 & 1.88 & 1.89 & 1.89 \\
\hline $6 \mathrm{NH}^{2}$ & 6 & 7870 & $3 \mathrm{Z}^{3} 5$ & 10.385. & $375^{2}$ & Whary & 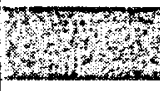 & 19.02 \\
\hline $\mathrm{NO}_{3}-$ & 1.55 & & 14.95 & 1.50 & 14.95 & 0.10 & 19.60 & 1.00 \\
\hline $\mathrm{sso}-4$ & 1795 & mon & 4924 & 10.97 & 6974 & 998 & 6047 & 625792 \\
\hline $\mathrm{PO}_{4}^{2-}$ & & 64.30 & 57.05 & $\mathbf{5 . 7 1}$ & 57.05 & 64.00 & 64.00 & \\
\hline $\mathrm{HOO}_{8}$ & 20,50 & pxyze & $7890 \mathrm{O}$ & $6 x^{3} 89$ & 218.90 & 7900 & 11900 & \% 1900 \\
\hline Glucose & & 11.10 & 5.55 & 0.56 & & 5.55 & 5.55 & 5.55 \\
\hline Heth & 3it 6 & 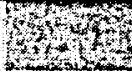 & $3 x_{2}$ & Why & 37 & 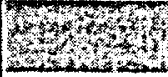 & $W^{6}, w^{2}$ & W67n \\
\hline $\mathrm{SiO}_{3}{ }^{2-}$ & 9.61 & & & & & . & & \\
\hline
\end{tabular}




\section{METHODS}

\section{A. Media}

The growth media formulations were generated using The Geochemist's Workbench, a geochemical modeling code. 'The media formulations were based on M9 defined bacterial medium and a ten-fold concentration $(10 \mathrm{X})$ of J13 YM pore water (Table 1). ${ }^{2,3}$ The concentrations of chloride and bicarbonate ions in the "YM Complete" medium were fixed at $10 \mathrm{X} \mathrm{J} 13$ levels, since these ions can affect corrosion rates and $\mathrm{pH}$. The levels of organic carbon (as added glucose), phosphate, sodium, potassium, nitrogen (as nitrate and ammonium), and magnesium ions in YM Complete medium approached those found in M9 (Table 1). Sulfate concentration was increased in order to maintain electrical neutrality. Other media used in these studies were variations of YM Complete medium. The "Dilute Complete" medium was 0.1X YM Complete medium. The "Carbon Deficient" and "Phosphate Deficient" media contained no organic carbon or phosphate, respectively, approximating the levels of these species found in J13 pore water. ${ }^{3}$ The concentrations of the other macronutrients, sulfate and nitrogen, were likewise adjusted in "J13-SO " and "J13-NO respectively, by decreasing them to match those found in 1X J13 (Table 1). Finally, all experimental media are predicted to have a $\mathrm{pH}$ of 7.2 .

\section{B. Growth Conditions}

Growth rates of $\mathrm{YM}$ bacteria were determined by periodically measuring cell densities in batch flask cultures and continuously fed microcosms; both contained YM tuff as bacterial inoculum. YM tuff was aseptically collected from YM Exploratory Studies Facility alcoves 5,6 , and 7 and was then aseptically crushed $(1.68 \mathrm{~mm}$ $2.38 \mathrm{~mm}$ ) and homogenized. Batch cultures were contained in $125 \mathrm{ml}$ flasks with $5 \mathrm{~g}$ of crushed tuff and $20 \mathrm{ml}$ of indicated media. They were incubated at $30^{\circ} \mathrm{C}$ with continuous agitation $(150 \mathrm{rpm})$, and media were not replenished in these systems. Microcosms, however, initially contained $50 \mathrm{~g}$ of crushed YM tuff and $200 \mathrm{ml}$ of indicated media and were continuously supplied with fresh media $(5 \mathrm{ml} / \mathrm{hr})$. All microorganisms were incubated at $22^{\circ} \mathrm{C}$ and were contained within the microcosm vessel through the use of filters $(0.2 \mu \mathrm{m})$ fitted on outlets (Fig. 1). Sterile control batch and microcosm systems contained crushed YM tuff that was gamma-irradiated (3 Mrads) by exposure to a ${ }^{60} \mathrm{Co}$ source; these were incubated in YM Complete medium.

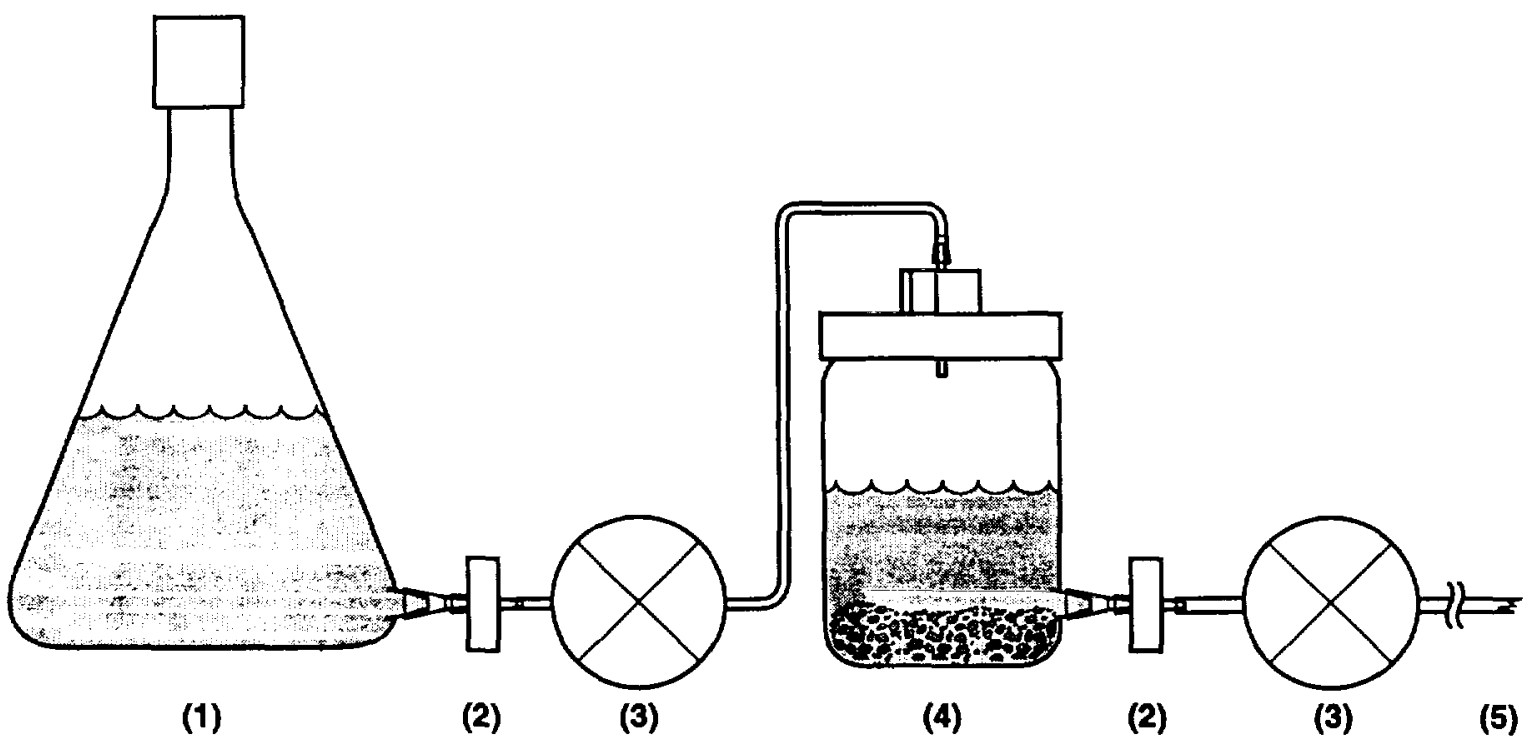

Fig. 1. Configuration of microcosms. Each individual microcosm was composed of a 1 liter reservoir tank containing sterile media (1), that was fed through a $0.2 \mu \mathrm{m}$ in-line filter (2) by means of a peristaltic pump (3), into a $500 \mathrm{ml}$ modified spin flask that contained crushed $\mathrm{YM}$ tuff (4). Bacteria were maintained within the spin flask by means of second $0.2 \mu \mathrm{m}$ in-line filter, and the outflow (5) rate was regulated by another peristaltic pump. Sterility was maintained throughout the system except in the tuff-containing vessel (4). 


\section{Cell Density Determinations}

Cell densities were determined by live plating." The aqueous phase of microcosms and batch cultures were periodically sampled, serially diluted, and plated on R2 agar (Difco). Plates were incubated at $30^{\circ} \mathrm{C}$ until colonies (which arise from single cells) could be counted (24-36hr). Colonies were then enumerated, and the density of the original suspension (cells $/ \mathrm{ml}$ ) was calculated by multiplying the number of cells/plate by the total dilution factor.

\section{(a) Microcosm}

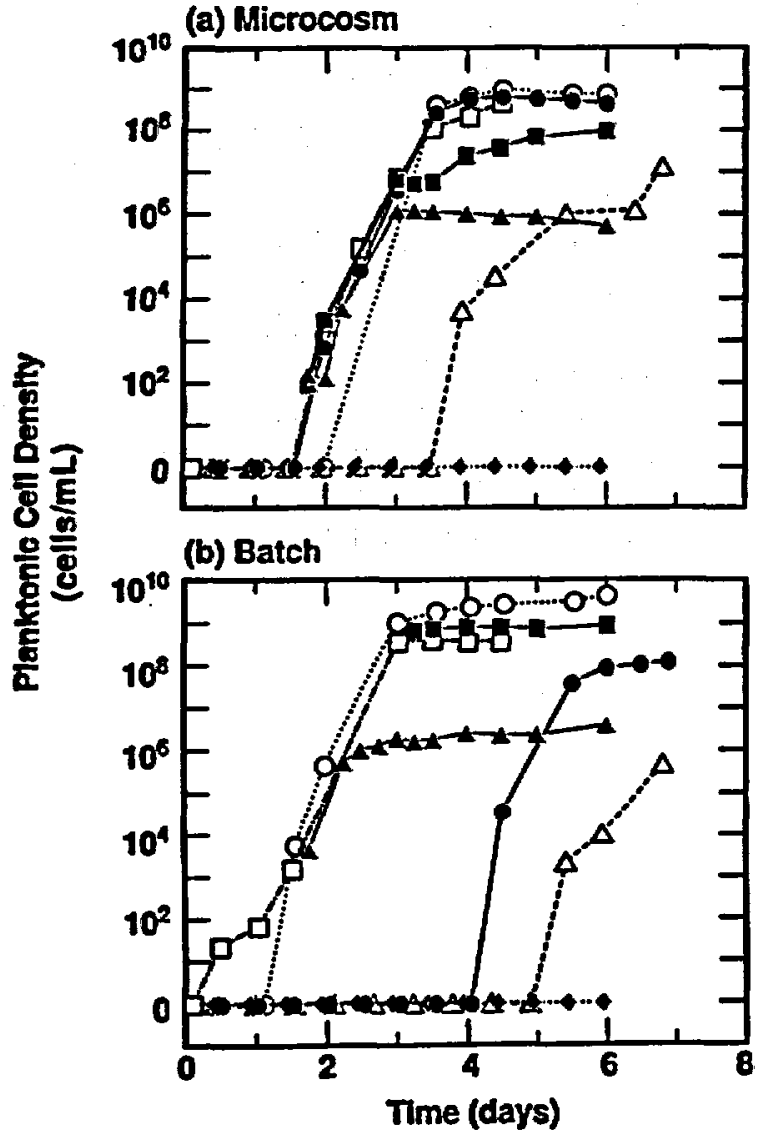

Fig. 2. Growth rates of $Y M$ bacterial communities as a function of the macronutrient concentration found in various growth media (described in text). Panel (a), Continuously fed systems; Panel (b), Unreplenished, aerated batch flask systems. $\mathbf{n}, \mathbf{M}$ Complete; $\mathbf{a}$, Dilute Complete; $\mathbf{\Lambda}$, Carbon Deficient; $\Delta$ Phosphate Deficient; $\bullet, J_{13}-\mathrm{NO}_{3} ; \mathrm{O} \mathrm{J13}-\mathrm{SO}_{4}$; $\bullet$, Sterile Control in YM Complete.

\section{RESULTS}

Despite decreased levels of macronutrients in all but the YM Complete-fed cultures, bacterial growth from YM tuff was detected in all batch and microcosm systems tested except those containing sterilized tuff (Figs. 2a, 2b).

Microcosm-grown cultures demonstrated similar growth rates, despite the absence of organic carbon and phosphate or the reduction of nitrogen and sulfate from their respective media (Fig. 2a). Excepting the Phosphate Deficient-grown culture and the sterile control, these cultures produced near-equivalent lag periods of approximately 2.0 days and similar doubling times averaging 2.0 hours (standard deviation $=0.14$ ). Maximum cell densities achieved in these cultures did differ, however, from approximately $10^{6}$ cells $/ \mathrm{ml}$ (Carbon Deficient media) to $10^{3}-10^{9} \mathrm{cells} / \mathrm{ml}$ (Dilute Complete

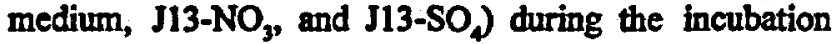
period of six days. In contrast, the culture incubated with Phosphate Deficient medium demonstrated a longer lag period of approximately 3.5 days and a doubling time of 4.8 hours, generating $10^{7}$ cells/ml after seven days of incubation (Fig. 2a).

Batch cultures, which were aerated and grown without media replenishment, showed similar growth trends when compared with microcosm cultures (Figs. 2a, 2b); however, community doubling times in batch cultures were slightly longer, averaging 2.3 hours (standard deviation $=0.26$ ) in all media except Phosphate Deficient and the sterile control. Again, variation in the maximal cell densities was dependent on media formulation, varying from $10^{6} \mathrm{cells} / \mathrm{ml}$ (Phosphate Deficient media) to greater than $10^{\circ}$ cells/ml ( J13-SO, media). Additionally, the initial lag periods of $\mathrm{J} 3-\mathrm{NO}_{3}$ and Phosphate Deficient media averaged 4-5 days compared with lag periods of 1-2 days in the other media.

\section{DISCUSSION}

Whole YM bacterial communities found in YM tuff demonstrated significant growth in defined media that approximated the composition of M9 medium but contained 10X J13 levels of chloride and carbonate. Nutrients that are used in the greatest quantities for bacterial metabolism ("macronutrients") were individually reduced to levels found in $\mathrm{YM}$ pore water, and significant growth was still observed. These findings strongly suggest that bacterial growth within YM is not limited by a lack of organic carbon, phosphate, nitrogen, or sulfate, at least under saturated, aerobic conditions. Sterilized YM tuff produced no growth, indicating that the observed 
bacterial growth in non-sterilized cultures originated from YMtuff.

The growth of microorganisms in the absence of added organic carbon (YM tuff contains no organic sources of carbon) suggests that bacterial carbon dioxide fixation accounted for growth under these conditions. Nitrogen and sulfate concentrations in YM pore water are also apparently sufficient to support microbial growth, as growth was observed when the concentrations of these species were reduced to $\mathrm{J} 13$ levels.

J13 pore water reportedly contains no phosphate, ${ }^{3}$ which is used in significant quantities for microbial metabolism; however, bacterial growth was also observed in both batch and microcosm cultures when phosphate was eliminated from growth media. Since YM tuff contains trace amounts of phosphate, ${ }^{5}$ dissolution due to microbial activities may account for the observed growth in Phosphate Deficient medium.

The results reported here are preliminary, but they strongly suggest that in situ YM nutrient levels may well be sufficient to support growth of endogenous bacteria. These findings also demonstrate the need for microbial induced corrosion studies of potential waste package materials.

\section{ACKNOWLEDGMENTS}

This work was performed under the auspices of the U.S. Department of Energy by Lawrence Livermore National Laboratory under Contract W-7405-ENG-48. This work is supported by Yucca Mountain Site Characterization Project, LLNL.

\section{REFERENCES}

1. C.M. Bethke. "The Geochemist's Workbench, Version 2.0: A Users Guide to Rxn, Tact, React, and Grplot," Hydrogeology Program, University of Illinois (1994).

2. J.H. Miller. Experiments in Molecular Genetics Cold Spring Harbor Laboratory Press, Cold Spring Harbor, N.Y. (1972).

3. J.M. Delany. "Reaction of Topopah Spring Tuff with Water: A Geochemical Modeling Approach Using the EQ3/6 Reaction Path Code," Lawrence Livermore National Laboratery report UCID-53631, Livermore, CA, November, 1985.

4. T.D. Brock, M.T. Madigan. Biology of Microorganisms, p. 310-311, Prentice Hall, Englewood Cliffs, NJ (1991).

5. D.E. Broxton, D.L. Bish, R.G. Warren. "Distribution and chemistry of diagenetic minerals at Yucca Mountain, Nye County, Nevada," Clays and Clay Minerals, 35:89-110, (1987). 